\title{
Article \\ Food in Slow Tourism: The Creation of Experiences Based on the Origin of Products Sold at Mercat del Lleó (Girona)
}

\author{
Francesc Fusté-Forné ${ }^{1, *}$ (i), Paula Ginés-Ariza ${ }^{2}$ and Ester Noguer-Juncà ${ }^{3}$ (i) \\ 1 Department of Business, University of Girona, 17004 Girona, Spain \\ 2 Faculty of Tourism, University of Girona, 17004 Girona, Spain; u1948266@campus.udg.edu \\ 3 Department of Economics, University of Girona, 17004 Girona, Spain; ester.noguerjunca@udg.edu \\ * Correspondence: francesc.fusteforne@udg.edu or researchexperiencetourism@gmail.com
}

check for

updates

Citation: Fusté-Forné, F.;

Ginés-Ariza, P.; Noguer-Juncà, E.

Food in Slow Tourism: The Creation

of Experiences Based on the Origin of

Products Sold at Mercat del Lleó

(Girona). Heritage 2021, 4, 1995-2008.

https://doi.org/10.3390/

heritage 4030113

Academic Editors: Dmitry A. Ruban and Francesco Soldovieri

Received: 16 July 2021

Accepted: 24 August 2021

Published: 26 August 2021

Publisher's Note: MDPI stays neutral with regard to jurisdictional claims in published maps and institutional affiliations.

Copyright: (c) 2021 by the authors. Licensee MDPI, Basel, Switzerland. This article is an open access article distributed under the terms and conditions of the Creative Commons Attribution (CC BY) license (https:/ / creativecommons.org/licenses/by/ $4.0 /)$.

\begin{abstract}
Previous studies have highlighted the role of local food as a source of destination differentiation and tourist motivation, and as part of the understanding of slow food tourism. However, few previous researchers have discussed the proximity degree of products delivered in food tourism spaces such as markets, and how they contribute to the creation of slow tourism experiences. Based on the analysis of the origin of fruits and vegetables being sold at Mercat del Lleó, the municipal market of Girona (Catalonia, Spain), this paper investigates the value of local supply in an urban food tourism system. Fieldwork included nine interviews with market vendors, and data regarding 301 fruits and vegetables sold at the market were obtained. While results show a wide representation of local and regional produce, fruits and vegetables of national and international origin predominate over proximity products. The article reveals that there is still potential to improve the relationships between local food, identity promotion, and the sustainable experiences that attract slow tourists to urban destinations.
\end{abstract}

Keywords: culinary heritage; food market; gastronomy tourism; regional development; slow tourism; urban destination

\section{Introduction}

Food is an example of heritage that represents a manifestation of the "sense of place" [1,2]. Drawing upon local products and culinary traditions, food refers to the dynamics of production and consumption, which are illustrative of cultural and natural heritage $[3,4]$. Food tourism is a growing niche form of tourism that lies at the core of destination management and marketing [5]. Changes in tourists' behaviors, needs and expectations generate continuous modifications to the planning and development of services [6]. Tourists have more and more knowledge, more purchasing power and more free time to travel [7]. As a consequence, many of them look for authentic experiences that are typical of the host culture, with food heritage being among the most important. Food is an avenue to express a place's identity and promote its natural and cultural geographies [8-11]. When tourism value is awarded to "food", Flavián and Fandos [12] describe two possible scenarios. First, food could be viewed as the main reason for tourism. Second, it could be seen as a complementary experience that adds major value to the trip (see, for example, [13]). In both cases, food emerges as an avenue toward the configuration of a food-based tourism offering that relies on locally grown products and can lead to the development of slow food tourism experiences [14].

This research understands slow tourism as a journey where tourists seek authentic experiences that depend on aspects of heritage such as food, for example, "taking time to browse the local market" [15] (p. 77), in order to build an attachment to people and places [16]. Slow tourism is a form of travel born in Italy in the 1980s from the "Slow Food Movement" [17-20] as a local system of resistance to the standardization of food [21]. Slow tourism promotes cultural, economic and environmental sustainability through 
travel [22-25], and brings people the opportunity to discover local heritage [19], where food plays a pivotal role [26] as a way to connect culturally with the local community and the local landscape. In this sense, slow food tourism is an example of the slow movement [26], whose objective is to gather an authentic experience combining the enjoyment of local foods and beverages with the knowledge of gastronomic practices and resources [27].

Catalan culinary heritage in general and Girona culinary heritage in particular feature a diverse and rich gastronomic landscape [28-31] that includes a wide inclusion of both mountain and sea products. In this sense, the most typical dishes of Catalan cuisine are "canelons" (cannelloni), "pa amb tomàquet" (bread with tomato), or "crema catalana" (Catalan cream). The study of food tourism in Catalonia has been predominantly focused on the impacts of food tourism management and marketing on rural environments [32]. In addition, previous research has developed the territorial dimension of food tourism [33] and investigated the role of food tours [34], particularly in the case of wine [35]. From an urban perspective, the relevance of food markets is acknowledged as a path to protect and promote food in urban tourism, and some studies have specifically reviewed the Boqueria market in Barcelona [36,37] and municipal markets in the Costa Daurada region [38]. While previous research has mostly analyzed food tourism in Barcelona [39], other areas within Catalonia remain underrepresented in food tourism research, despite their local food value, as in the case of Girona. Drawing from a study case approach, this article aims to fill in this research gap and analyze the meanings embedded in the origin of foods available at its municipal market, Mercat del Lleó, as a relevant factor in the management and marketing of tourist experiences. In particular, this paper understands the value of local food as a symbol of territorial identity and a means to attract tourists, in order to explore the implications of slow experiences in food tourism in urban destinations.

\section{The Value of Local Food in Food Tourism Systems}

Food tourism relies on the connection between gastronomy and identity, and how this union becomes a tourist attraction [9]. According to Raina et al. [40], "food tourism will be more or less developed, depending on the connection between cuisine and local culture, as cuisine plays an important role in the tourist experience and satisfaction and represents the cultural heritage of the destination" (p. 14188). This is manifested, for example, by udon noodles [41], a Japanese cultural symbol and a tourist attraction. In particular, Kim and Iwashita [41] add to the definition of food tourism the notion of travel to a specific location, where the main motivation is to enjoy its local products, flavors and aromas, and to learn about its cooking styles and culinary traditions. Previous research showcases that there is a wide range of opportunities to develop a tourism experience that relies on food heritage $[42,43]$ This can be experienced through local food producers and culinary events, or even by eating in a specific restaurant or visiting a food market.

Specifically, the United Nations World Tourism Organization [44] (p. 27) describes food tourism as a stimulator of the local economy because it "provides the opportunity for job creation and the development of local economies, which in turn positively affects other sectors. It is also a major contributor to overcoming seasonality". In addition, according to Seyitoğlu and Ivanov [45], entrepreneurs are aware of the special value of gastronomy as a motivator of tourism that can generate economic profits. Quan and Wang [46] affirm that food tourism can offer an opportunity for food producers, especially in rural areas, to add value to their products. The understanding of local food also refers, according to Morris and Buller [47], to "the development of mechanisms or systems of food supply that are in some ways alternative to the conventional channels (particularly those associated with the multiple retailers and large food processing companies)" (p. 559), and include, for example, farmers' markets or local fairs. These activities are often the basis of food tourism [48]. According to Ferran Adrià (quoted in [49]), tourism promotes the sustainability of the gastronomic sector in a city.

The notion of slow in tourism refers to "making real and meaningful connections with people, places, culture, food, heritage and the environment" [22] (p. 78), where slow 
tourism practices may include the discovery of the local uniqueness and "eating at local restaurants, buying in local markets or direct from producers, trying local drinks, beer, and wine" [22] (p. 78). Both public and private stakeholders within destinations must protect and promote food heritage and traditions, and also include slow food menus as part of their restaurant offer. Slow production is the driver for slow consumption. In this sense, Fusté-Forné and Jamal [14] reveal that "calls for slow tourism and slow food experiences reflect the need for a conscious, active way of being and living, oriented not to speeded-up lifestyles driven by mass consumption, business competition and jockeying for market position, but to slow, responsible, mindful relationships and practices that foster resilience, sustainability and social plus ecological well-being" (p. 228). Slow tourism is a conscious and alternative attitude [50].

In Spain, according to the KPMG study [49], a food tourist "spends $20 \%$ more than an average tourist" (p. 49). This percentage is even higher than the statistics suggest, since, as previously mentioned, food comprises a third of tourist spending [11]. This is due to the fact that, as Richards [51] stated, all tourists have to eat during the trip. According to Henderson [52], the expenditure on food includes not only the consumption of food, but also the purchase of local food products as souvenirs. There is a direct connection between gastronomic motivation and tourist spending [53] and food markets emerge as a crucial tourist attraction.

In Catalonia, the agri-food sector is considered the main economic sector of the region, generating a turnover equivalent to $16.28 \%$ of its GDP [54]. This showcases the relevance of primary industries for the economic development of a region. It is also an essential sector for food tourism because without agri-food activity there would be no quality food. In this sense, food tourism acknowledges the relationship between food and agriculture [55]. While food tourism is frequently viewed as an opportunity, it is also confronted by the food globalization phenomenon, which has paradoxically been accentuated by the development of this segment of tourism [52,56]. Food tourism has to protect and promote both past and future authenticity [44]. This is the main challenge for the tourism industry. According to the UNWTO, "promotion should be global, but the experience local. Food tourism is a form of cultural preservation and should be configured around the quality and authenticity of the product and territory" [44] (p. 27). The difficulty is ensuring that each food experience represents the culinary authenticity of the specific destination. In this sense, a crucial factor is the proximity of food [57], which is the focus of this paper.

Previous research has also discussed the role of local food in building a regional or national identity [58,59]. Gastronomy is a cultural expression that communicates a particular culinary identity shared by a group of people [60], which relies on both food production and consumption [61]. There are different factors that contribute to the building of identity through food, for example, "depending on the region, geographical environment, climate, economy and society" [62] (p. 881). This is also important in countries whose national cuisine is formed by different regional food heritages, such as Mexico [59]. In addition, a particular cuisine is changing constantly due to culinary influences [63], and the typical food of a region could be considered "traditional" for different reasons, such as the cooking style, the consumption process, or the ingredients. Food tourism can valorize both the tangible and intangible heritage of a culture.

Quan and Wang [46] stated that tourists want new gastronomic experiences to make their trips more authentic, and these experiences sometimes become commodified [64]. As a result, the authenticity of a destination's gastronomy is adapted to satisfy tourism demands [65]. According to Scarpato and Daniele [66], the relevance and reappraisal of the concept of sense of place include the cultural and natural elements of a food destination [11] in order to achieve sustainable food tourism [67]. The globalization of food also accentuates the development and planning of local products [68] that protect and promote the characteristics of a place and its people [69]. In this sense, the article aims to analyze how this is exemplified in the city of Girona, north-eastern Catalonia, according to the origin of the fruits and vegetables available at its municipal market. 


\section{Methods}

The objective of this article is to analyze food tourism experiences based on the origin of the food being sold at markets, in order to observe the potential for authentic food tourism activities and practices in the context of slow tourism experiences. Girona is a tourist destination located in the north-eastern side of Catalonia, north-eastern Spain, south-western Europe (Figure 1), in a Mediterranean region where gastronomy plays an increasingly relevant role. Within the context of the UNESCO acknowledgment of the Mediterranean diet in 2013 as Intangible Cultural Heritage, it is reported that "the Mediterranean diet emphasizes the values of hospitality, neighborliness, intercultural dialogue and creativity, and a way of life guided by respect for diversity" [70]. In the framework of the Mediterranean diet, local food "markets also play a key role as spaces for cultivating and transmitting the Mediterranean diet during the daily practice of exchange, agreement and mutual respect" [70]. In recent years, the city of Girona has become a major cultural tourist destination due to the artistic and historical value of its medieval Old Town [71,72]. The city is also famous for the El Celler de Can Roca restaurant, a three-Michelin-starred restaurant that, in 2013 and 2015, was considered the best restaurant in the world. This accolade resulted in a boom in food tourism in Catalonia in general, and in Girona in particular [73] where local food emerges as a factor of tourist attraction [74]. The municipal market of the city, called Mercat del Lleó, is the main point of distribution for local food in the region. This market is not only a commercial hub but also a cultural and social mediator within rural and urban relationships [75]. In the current context of the COVID-19 pandemic, tourism in Catalonia is slowly recovering [76]; however, it must be acknowledged that tourism has not fully recovered from the lockdowns and travel restrictions that have occurred since March 2020 [77].

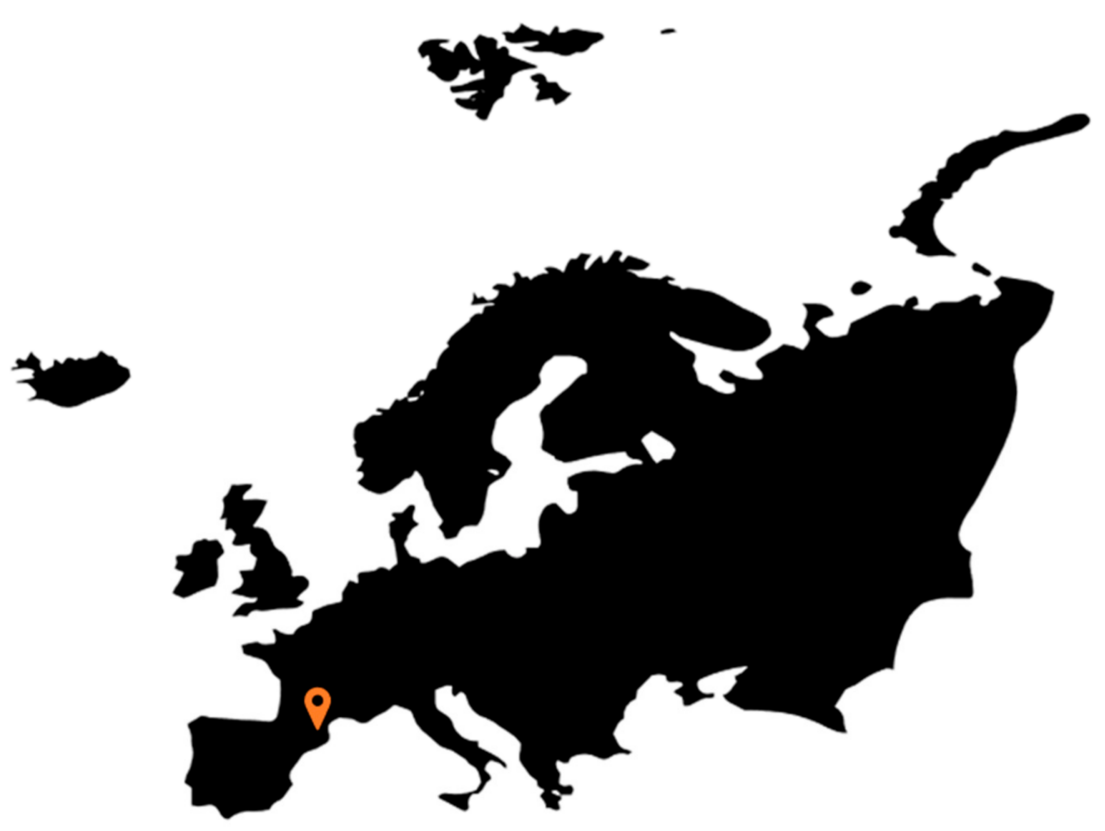

Figure 1. Location of Girona, Catalonia (own source).

Following previous research [38], this paper investigates the origin of foods available at the municipal market of Girona. In particular, data collection is focused on fruits and vegetables because within the context of products being sold at municipal markets, "fruits and vegetables are the products that present a greater variety, and, therefore, a greater weight in the total" [38] (p. 221). Mercat del Lleó includes nine places that sell fruits and vegetables [78] and all of them are included in the sample. Fieldwork and data collection were carried out during the last week of June and the first week of July 2021. A total of three visits were made to the Mercat del Lleó, where nine interviews were conducted with 
vendors, in order to collect the products that were being sold and ascertain their origin. Data collection included all the fruits and vegetables sold at the market, which were sold by nine vendors. The research analyzed the entire sample of fruits and vegetables. The participants were questioned about the types of fruits and vegetables sold, and the origin of the fruits and vegetables. The evidence from the interviews is the list of products sold, which comprises the elements of analysis in this research and the reason why the profiles of the interviewees are judged as not relevant to the discussion of the results. As a result of the data collection, a total of 301 food products, both fruits and vegetables, were obtained. In relation to each product, the following elements were annotated: the commercial name of the food store; the name of each product; its place of origin; and the degree of proximity. Regarding the proximity, the classification included four types of products based on the place of origin: local (when food comes from the county in which the market is located, or from its bordering counties), regional (when it comes from Catalonia), national (when it comes from Spain) and international (when it comes from any country in the world).

\section{Results}

The results of this research analyzed a total of 301 products. Table 1 reveals that there are 48 different types of fruits and vegetables and gives their proportions of weight. Among them, apple, tomato, melon, peach, pear, onion and potato are the most widely represented. In relation to their origin, Table 2 highlights the relevance of products from local (95) and national (110) origin, which predominate over regional (43) and international (53) fruits and vegetables. In this sense, the analysis of data shows that $31.56 \%$ of products have a local origin, $14.29 \%$ have a regional origin, $36.54 \%$ have a national origin, and $17.61 \%$ have a global origin. The sum of local and regional products is weighted less than national and international products.

Table 1. Fruits and vegetables available at Mercat del Lleó (own source).

\begin{tabular}{ccc}
\hline Product & N & $\%$ \\
\hline Apple & 23 & $7.64 \%$ \\
Apricot & 8 & $2.66 \%$ \\
Asparagus & 4 & $1.33 \%$ \\
Avocado & 9 & $2.99 \%$ \\
Banana & 9 & $2.99 \%$ \\
Bean & 5 & $1.66 \%$ \\
Blueberry & 1 & $0.33 \%$ \\
Broccoli & 4 & $1.33 \%$ \\
Cabbage & 3 & $1.00 \%$ \\
Carrot & 5 & $1.66 \%$ \\
Celery & 1 & $0.33 \%$ \\
Chard & 2 & $0.66 \%$ \\
Cherry & 10 & $3.32 \%$ \\
Coconut & 1 & $0.33 \%$ \\
Cucumber & 3 & $1.00 \%$ \\
Eggplant & 8 & $2.66 \%$ \\
Fig & 1 & $0.33 \%$ \\
Garlic & 6 & $1.99 \%$ \\
Ginger & 1 & $0.33 \%$ \\
Grapes & 4 & $1.33 \%$ \\
Grapefruit & 2 & $0.66 \%$ \\
Kiwi & 10 & $3.32 \%$ \\
Leek & 3 & $1.00 \%$ \\
Lemon & 7 & $2.33 \%$ \\
Lettuce & 6 & $1.99 \%$ \\
\hline
\end{tabular}


Table 1. Cont.

\begin{tabular}{ccc}
\hline Product & $\mathbf{N}$ & $\%$ \\
\hline Lime & 2 & $0.66 \%$ \\
Mango & 6 & $1.99 \%$ \\
Melon & 13 & $4.32 \%$ \\
Mushroom & 3 & $1.00 \%$ \\
Nectarine & 3 & $1.00 \%$ \\
Onion & 12 & $3.99 \%$ \\
Orange & 11 & $3.65 \%$ \\
Papaya & 3 & $1.00 \%$ \\
Paraguayan peach & 6 & $1.99 \%$ \\
Peach & 13 & $4.32 \%$ \\
Pear & 13 & $4.32 \%$ \\
Pepper & 11 & $3.65 \%$ \\
Pineapple & 6 & $1.99 \%$ \\
Plum & 7 & $2.33 \%$ \\
Potato & 12 & $3.99 \%$ \\
Pumpkin & 2 & $0.66 \%$ \\
Spinach & 1 & $0.33 \%$ \\
Strawberry & 3 & $1.00 \%$ \\
Sweet potato & 1 & $0.33 \%$ \\
Tangerine & 3 & $1.00 \%$ \\
Tomato & 20 & $6.64 \%$ \\
Watermelon & 7 & $2.33 \%$ \\
Zucchini & 7 & $2.33 \%$ \\
Total & 301 & $100.00 \%$ \\
\hline & & \\
& &
\end{tabular}

Table 2. Origin of fruits and vegetables being sold at Mercat del Lleó (own source).

\begin{tabular}{ccc}
\hline Origin & $\mathbf{N}$ & $\%$ \\
\hline Local & 95 & $31.56 \%$ \\
Regional & 43 & $14.29 \%$ \\
National & 110 & $36.54 \%$ \\
International & 53 & $17.61 \%$ \\
Total & 301 & $100.00 \%$ \\
\hline
\end{tabular}

In relation to the local origin (see an example in Figure 2) of fruits and vegetables, almost a third of them have their origin in the province of Girona, since they grow in the fields of Girona towns, like Fornells de la Selva or Santa Cristina d'Aro. Fruits and vegetables that have a regional origin (Figure 3) come mainly from the provinces of Lleida and Tarragona. On the other hand, products with national origin (Figure 4) have greater weight, and they come mainly from the southern regions of Spain, the Andalusian territories (mainly Almeria) and Murcia, and are fruits and vegetables that in some cases are not in season. For that reason, sellers cannot yet purchase some of these products from local farmers. At the national level, the availability of citrus fruits (mainly oranges) from Valencia is also relevant. Regarding those products with international origin (Figure 5), these are tropical fruits such as grapes or pineapples from Central and Latin America, or kiwis from New Zealand. It is also worth noting the international origin of some products, such as apples and pears from Chile, and tangerines from Argentina or South Africa. 


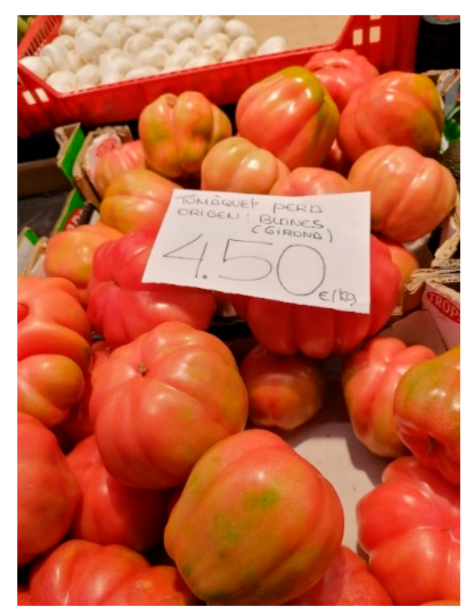

Figure 2. An example of a local product: tomatoes from Blanes, Girona (own source).

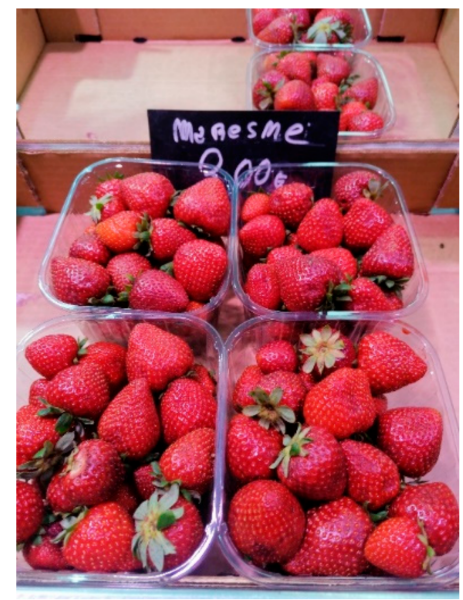

Figure 3. An example of a regional product: strawberries from Maresme, Catalonia (own source).

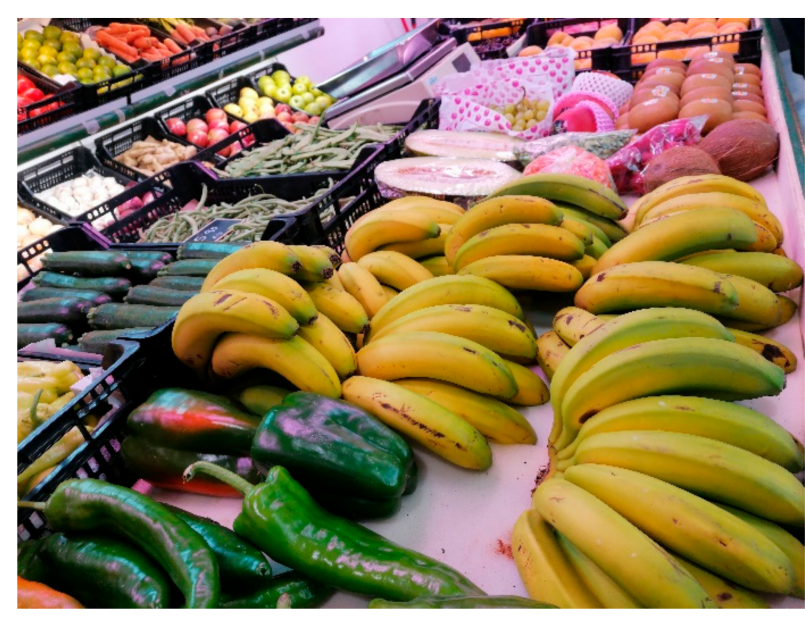

Figure 4. An example of a national product: bananas from the Canary Islands, Spain (own source). 


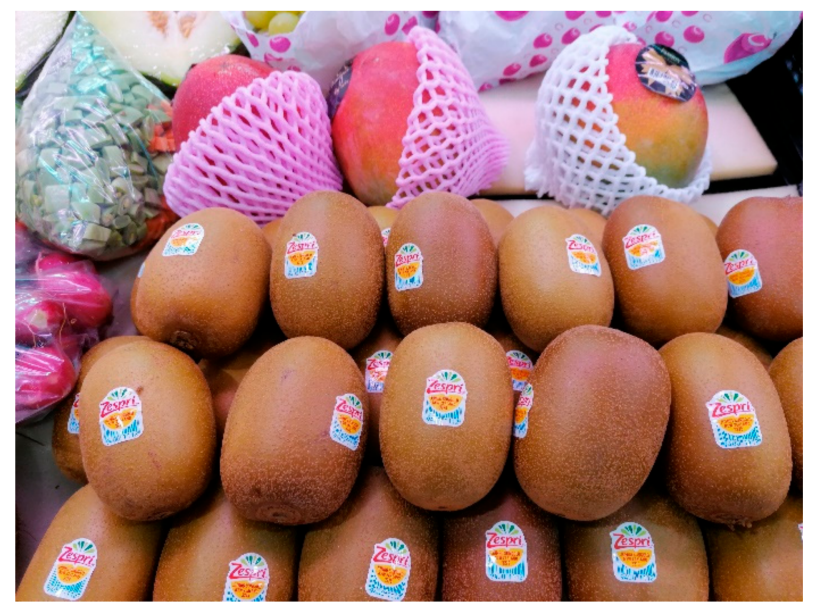

Figure 5. An example of an international product: kiwis from New Zealand (own source).

Finally, Table 3 shows the aggregated data in relation to the origin of each of the fruits and vegetables. In particular, the proximity can be independently analyzed per product. It is observed that apples are mostly locally grown, which is explained by the fact that Girona apples have a quality label (Protected Geographical Indication). However, some food stores sell apples from international markets, as mentioned above, such as Chile, but also from famous apple countries such as Italy and New Zealand. Tomatoes, melons and onions either come from Catalan and Spanish territories, where Andalusia and Murcia are major agricultural regions. Finally, while peaches grow in regional fields, pears predominantly come from national and international markets, and the origin of potatoes is both local and global.

Table 3. Fruits and vegetables available at Mercat del Lleó and their origin (own source).

\begin{tabular}{|c|c|c|c|c|c|}
\hline Product & Local & Regional & National & International & $\mathbf{N}$ \\
\hline Apple & 16 & 4 & - & 3 & 23 \\
\hline Apricot & 2 & 5 & 1 & - & 8 \\
\hline Asparagus & - & 1 & 2 & 1 & 4 \\
\hline Avocado & - & 1 & 6 & 2 & 9 \\
\hline Banana & - & - & 9 & - & 9 \\
\hline Bean & 5 & - & - & - & 5 \\
\hline Blueberry & - & - & 1 & - & 1 \\
\hline Broccoli & 2 & - & 2 & - & 4 \\
\hline Cabbage & 3 & - & - & - & 3 \\
\hline Carrot & 2 & - & 3 & - & 5 \\
\hline Celery & 1 & - & - & - & 1 \\
\hline Chard & 2 & - & - & - & 2 \\
\hline Cherry & 2 & 3 & 5 & - & 10 \\
\hline Coconut & - & - & - & 1 & 1 \\
\hline Cucumber & 2 & 1 & - & - & 3 \\
\hline Eggplant & 1 & 1 & 6 & - & 8 \\
\hline Fig & - & - & 1 & - & 1 \\
\hline Garlic & 5 & - & 1 & - & 6 \\
\hline Ginger & 1 & - & - & - & 1 \\
\hline Grapes & - & - & 2 & 2 & 4 \\
\hline Grapefruit & 1 & - & 1 & - & 2 \\
\hline Kiwi & - & - & - & 10 & 10 \\
\hline
\end{tabular}


Table 3. Cont.

\begin{tabular}{|c|c|c|c|c|c|}
\hline Product & Local & Regional & National & International & $\mathbf{N}$ \\
\hline Leek & 1 & - & 1 & 1 & 3 \\
\hline Lemon & 2 & 1 & 4 & - & 7 \\
\hline Lettuce & 5 & - & 1 & - & 6 \\
\hline Lime & - & - & 1 & 1 & 2 \\
\hline Mango & - & - & - & 6 & 6 \\
\hline Melon & 1 & 1 & 9 & 2 & 13 \\
\hline Mushroom & - & - & 2 & 1 & 3 \\
\hline Nectarine & 1 & 1 & 1 & - & 3 \\
\hline Onion & 6 & 2 & 4 & - & 12 \\
\hline Orange & 1 & 1 & 8 & 1 & 11 \\
\hline Papaya & - & - & - & 3 & 3 \\
\hline $\begin{array}{l}\text { Paraguayan } \\
\text { peach }\end{array}$ & 1 & 3 & 2 & - & 6 \\
\hline Peach & 3 & 7 & 3 & - & 13 \\
\hline Pear & 3 & 1 & 5 & 4 & 13 \\
\hline Pepper & 1 & 2 & 7 & 1 & 11 \\
\hline Pineapple & - & - & - & 6 & 6 \\
\hline Plum & 4 & 1 & 2 & - & 7 \\
\hline Potato & 4 & 1 & 2 & 5 & 12 \\
\hline Pumpkin & 1 & - & 1 & - & 2 \\
\hline Spinach & 1 & - & - & - & 1 \\
\hline Strawberry & 2 & - & 1 & - & 3 \\
\hline Sweet potato & - & 1 & - & - & 1 \\
\hline Tangerine & - & 1 & - & 2 & 3 \\
\hline Tomato & 8 & 3 & 8 & 1 & 20 \\
\hline Watermelon & 1 & - & 6 & - & 7 \\
\hline Zucchini & 4 & 1 & 2 & - & 7 \\
\hline Total & 95 & 43 & 110 & 53 & 301 \\
\hline
\end{tabular}

As a summary of the results, a similar proportion exists between local-regional and national-international food. As a consequence, while the origin of fruits and vegetables that come from the immediate surroundings of Girona is representative, data shows that a potential to improve local supply chains exists, as discussed in the next section.

\section{Discussion and Conclusions}

The theoretical section of this paper discussed the concept of food tourism $[5,42,79]$ and, in particular, has delved into the value of local food and gastronomy for the protection and promotion of identity and heritage, and as a source of tourism attraction $[45,63,68]$. The slow food tourism movement relies on local food heritages and practices as a way to show respect toward the environment and the host communities $[14,17,19]$. Previous research has focused on food tourism as a relevant type of tourism that includes a wide range of experiences (i.e., visits to food producers, restaurants or events) with a primary motivation: to taste local food. The current research understands products sold at markets, and their origin, as a differential attribute of the food tourism system in the city of Girona. This paper has discussed the role of local food in the offering of food tourism in Girona, drawing from the analysis of the origin of food being sold at the municipal market.

The gastronomy of Girona is a mixture of products from landscapes near the city, but also from national and international environments. This is a clear indicator of the strategic line that the city needs to follow for the development and promotion of slow food tourism. Like most European cities, Girona offers a wide range of fruits and vegetables from multiple origins. In this sense, previous research on food tourism consumption and production in another Spanish city, Santiago de Compostela, reveals that the food tourism experience is often standardized, which "supposes a high reduction in the diversity of the product that can be offered and produced in terms of proximity, and its territorial differentiation, compared to the usual consumption of the Galician population, to the potential agricultural 
production by associated foodshed, and to the gastronomic advertising through official web pages" [55] (p. 1). The significance of this research relies on the understanding of the experiences derived from the local and regional agricultural production and their potential to promote a taste of the land, the uniqueness of a destination, and its cultural and natural heritage. In addition, it focuses on a city where few studies have been conducted, as a means to explore the relationships between food and tourism in Catalonia.

The results of this research show that there is a similar weight of local-regional foods and national-international foods, which slightly exceeds the proximity product. Although this does not confirm the strength of proximity fruits and vegetables and therefore of a slow tourism experience, it is obvious that products from Girona and its surroundings represent a distinctive element when selling fruits and vegetables, as also reported in previous research [38]. Local products are presented as a path to explore a place through its food heritage $[80,81]$. However, global products can also satisfy tourists who may prefer to find food that they are used to when they travel [46]. Food markets are spaces where the origin of products and the configuration of the supply chains determine to what extent they can provide slow tourism experiences. This study informs local and regional stakeholders about the origin of the fruits and vegetables being sold and what type of food identity is being promoted. This is relevant for a sustainable future of tourism and enhances the value of local food for the management and marketing of food-based tourism.

The main limitation of this research is that it relies solely on the origin of fruits and vegetables available at the municipal market of the city as a means to discuss the planning and development of slow food tourism. While the relationships between food and tourism acknowledge a diverse landscape of experiences, this research is exclusively based on the discussion of the origin of food sold at the municipal market of Girona, which limits the generalization of the results. Further research must also analyze other factors that affect food supply and demand. On the one hand, from a supply perspective, it is important to further scrutinize the economic impact of supply chains and the elements that inform the development of the marketing strategy of both producers and sellers, in order to understand the dynamics of production, prices, distribution and promotion. On the other hand, future studies should also explore the visitor experience from the perspective of tourist behavior, motivation and satisfaction. In addition, it is important to note that data was collected in the northern hemisphere during summer, which also influences the results presented. As a consequence, the proportion of fruits and vegetables from different origins will vary with the seasons, which will require further analysis to provide generalizable results and also to compare the food landscape between periods. This may also lead to studies that analyze the influence of global issues like climate change on local environments and growing seasons.

It is obvious that more empirical research is needed to assess whether there is a sufficient supply of local cuisine to satisfy visitors, or whether the city needs to do more to use its local food products to develop slow tourism experiences. Previous research suggests that local food markets are a gateway to learning a destination's food heritage $[82,83]$, and to taste local products that explain the culinary identities of Girona-its gastrospeak [84]. A local offer of food tourism experiences must acknowledge both a specific locality (Girona) and its surroundings (mainly the Costa Brava), in order to preserve the uniqueness of local products and the gastronomic identity of the region. In this sense, the most important practical implication of this research is the relevance of local food markets as a source for food tourism experiences. This research has also demonstrated that there is still potential for growth in the city with regard to the local origin of fruits and vegetables available at Mercat del Lleó, and the subsequent activities and practices based on the development of a slow food identity. Both public and private stakeholders must use the results of this research to design food tourism strategies that are based on local food heritages (a local fruit), local culinary traditions (the way a local fruit is cultivated and prepared) and local gastronomic experiences (a local fruit in a restaurant menu) that not only protect our landscape but also promote our lifestyle. 
In order to further investigate the integration of local food into tourism systems, it must be acknowledged that the potential for developing food tourism will depend on many more factors than merely the food available in the local markets. For example, the rural and urban relationships, the seasonality of demand, the food tourist's consumption and motivations, and also the role of restaurant services. In particular, restaurants are visited by both locals and tourists, whether or not they are interested in gastronomy. Restaurants are spaces where people come into contact with food and, therefore, with the region's gastronomic identity and heritage through local dishes and beverages. Empirical work that analyzes the use of local fruits and vegetables in restaurant menus can also provide a more robust picture of the topic, also in relation to the perspectives of both locals and visitors.

Furthermore, the paper expands the literature focused on the development of local food tourism in urban destinations by acknowledging the significance of a local product as a basic badge to configure the food tourism identity of urban destinations, as it does in rural areas. This paper innovatively studies the roles played by local food and slow tourism in urban environments, which are lesser-studied areas in food tourism. Food is a path to make connections with people and places when traveling [22]. In the framework of slow food tourism, destinations must deliver bioregional food experiences that are rooted in the local "sense of place" [14] and, at the same time, celebrate food as a manifestation of local heritage. For example, destinations must allow tourists to try the local produce first-hand and include the retail sector as part of their gastronomic offer, in order to link production and consumption, and build sustainable and local-based food supply chains. If the offering is global, tourists will simply eat. However, if it is local, differentiated and unique, restaurants and other food services will be able to provide a genuine visitor experience that relies on vernacular products. The research provides evidence that Girona could become a stronger gastronomic city, with its own identity, regardless of the influence of star chefs. This would attract more food tourists, who are coming to experience a different kind of food-unique local gastronomy and its culinary landscapes and heritages-from what they are used to [46]. It is possible to find a variety of fruits and vegetables, from different origins, which gives stakeholders the opportunity to meet a greater part of visitors' demands, but may this lead to a potential loss of the "sense of place", and of links to the region's history and culinary roots?

Author Contributions: Conceptualization, F.F.-F., P.G.-A. and E.N.-J.; methodology, F.F.-F., P.G.-A. and E.N.-J.; writing-original draft preparation, F.F.-F., P.G.-A. and E.N.-J.; writing-review and editing, F.F.-F., P.G.-A. and E.N.-J. All authors have read and agreed to the published version of the manuscript.

Funding: This research received no external funding.

Institutional Review Board Statement: Not applicable.

Informed Consent Statement: Informed consent was obtained from all participants.

Data Availability Statement: Data is contained within the article.

Acknowledgments: The authors would like to thank the vendors in Mercat del Lleó.

Conflicts of Interest: The authors declare no conflict of interest.

\section{References}

1. Bessière, J. 'Heritagisation', a challenge for tourism promotion and regional development: An example of food heritage. J. Herit. Tour. 2013, 8, 275-291. [CrossRef]

2. Timothy, D.J. Heritage Cuisines: Traditions, Identities and Tourism; Routledge: London, UK, 2015.

3. Berno, T.; Fusté-Forné, F. Imaginaries of cheese: Revisiting narratives of local produce in the contemporary world. Ann. Leis. Res. 2020, 23, 608-626. [CrossRef]

4. Miele, M.; Murdoch, J. The practical aesthetics of traditional cuisines: Slow food in Tuscany. Sociol. Rural. 2002, 42, 312-328. [CrossRef]

5. Ellis, A.; Park, E.; Kim, S.; Yeoman, I. What is food tourism? Tour. Manag. 2018, 68, 250-263. [CrossRef]

6. $\quad$ Lew, A.A.; Hall, C.M.; Williams, A.M. The Wiley Blackwell Companion to Tourism; John Wiley \& Sons: Oxford, UK, 2014. 
7. UNWTO. Global Report on Food Tourism; UNWTO: Madrid, Spain, 2012.

8. Dixit, S.K. The Routledge Handbook of Gastronomic Tourism; Routledge: London, UK, 2019.

9. Everett, S.; Aitchison, C. The role of food tourism in sustaining regional identity: A case study of Cornwall, South West England. J. Sustain. Tour. 2008, 16, 150-167. [CrossRef]

10. Fusté-Forné, F. Seasonality in food tourism: Wild foods in peripheral areas. Tour. Geogr. 2019, 1-21. [CrossRef]

11. Tresserras, J.J.; Medina, F.X. Patrimonio Gastronómico y Turismo Cultural en el Mediterráneo; Ibertur: Barcelona, Spain, 2008.

12. Flavián, C.; Fandos, C. Turismo Gastronómico: Estrategias de Marketing y Experiencias de Éxito; Universidad de Zaragoza: Zaragoza, Spain, 2011.

13. McKercher, B. Cultural tourism market: A perspective paper. Tour. Rev. 2020, 75, 126-129. [CrossRef]

14. Fusté-Forné, F.; Jamal, T. Slow food tourism: An ethical microtrend for the Anthropocene. J. Tour. Future 2020, 6, 227-232. [CrossRef]

15. Caffyn, A. The slow route to new markets. Tour. Insights 2009.

16. Sthapit, E.; Björk, P.; Coudounaris, D.N. Emotions elicited by local food consumption, memories, place attachment and behavioural intentions. Anatolia 2017, 28, 363-380. [CrossRef]

17. Dickinson, J.; Lumsdon, L. Slow Travel and Tourism; Earthscan: London, UK, 2010.

18. Huang, T.-Y.T.; Jordan, E.J. Exploring tourists' slow food experience: Perspectives from slow tourism. Travel Tour. Res. Assoc. Adv. Tour. Res. Glob. 2021, 1, 1-6.

19. Meng, B.; Choi, K. The role of authenticity in forming slow tourists' intentions: Developing an extended model of goal-directed behavior. Tour. Manag. 2016, 57, 397-410. [CrossRef]

20. Shang, W.; Qiao, G.; Chen, N. Tourist experience of slow tourism: From authenticity to place attachment-A mixed-method study based on the case of slow city in China. Asia Pac. J. Tour. Res. 2020, 25, 170-188. [CrossRef]

21. Petrini, C. Slow Food Nation: Why Our Food Should Be Good, Clean, and Fair; Rizzoli International Publications: New York, NY, USA, 2013.

22. Caffyn, A. Advocating and implementing slow tourism. Tour. Recreat. Res. 2012, 37, 77-80. [CrossRef]

23. Le Busque, B.; Mingoia, J.; Litchfield, C. Slow tourism on Instagram: An image content and geotag analysis. Tour. Recreat. Res. 2021, 1-8. [CrossRef]

24. Oh, H.; Assaf, A.G.; Baloglu, S. Motivations and goals of slow tourism. J. Travel Res. 2016, 55, 205-219. [CrossRef]

25. Valls, J.F.; Mota, L.; Vieira, S.C.F.; Santos, R. Opportunities for slow tourism in Madeira. Sustainability 2019, 11, 4534. [CrossRef]

26. Ernszt, I.; Marton, Z. An emerging trend of slow tourism: Perceptions of hungarian citizens. Interdiscip. Descr. Complex Syst. 2021, 19, 295-307. [CrossRef]

27. Petrini, C.; Padovani, G. Slow Food Revolution: Da Arcigola a Terra Madre: Una Nuova Cultura del Cibo e Della Vita; Rizzoli: Milano, Italy, 2005.

28. Pla, J. El Que Hem Menjat; Destino Ediciones: Barcelona, Spain, 1972.

29. Pomes, J. Catalan Cuisine; Triangle Postals: Sant Lluís, Spain, 2020.

30. Riera, A.; Santanach, J. El Patrimoni Gastronòmic Català i la Seva Cuina; Generalitat de Catalunya: Barcelona, Spain, 2020.

31. Song, H.R.; Riera, A. A Taste of Barcelona: The History of Catalan Cooking and Eating; Rowman \& Littlefield: London, UK, 2019.

32. Fusté-Forné, F.; Mundet, L. A land of cheese: From food innovation to tourism development in rural Catalonia. J. Tour. Cult. Chang. 2020, 19, 166-183. [CrossRef]

33. Leal Londoño, M.P.; López Palomeque, F. La dimensión territorial del turismo gastronómico en (Cataluña España). Una interpretación a través de la Geografía Económica relacional. Boletín Asoc. Geógrafos Españoles 2017, 74, 93-116. [CrossRef]

34. Jeambey, Z. Rutas gastronómicas y desarrollo local. PASOS Rev. Tur. Patrim. Cult. 2016, 14, 1187-1198.

35. Medina, F.X.; Tresserras, J. Turismo enológico y rutas del vino en Cataluña. Análisis de casos: DO Penedès, DO Priorat y DO Montsant. PASOS Rev. Tur. Patrim. Cult. 2008, 6, 493-509. [CrossRef]

36. Dimitrovski, D.; Crespi-Vallbona, M. Role of food neophilia in food market tourists' motivational construct: The case of La Boqueria in Barcelona, Spain. J. Travel Tour. Mark. 2017, 34, 475-487. [CrossRef]

37. Dimitrovski, D.; Crespi Vallbona, M. Urban food markets in the context of a tourist attraction—La Boqueria market in Barcelona, Spain. Tour. Geogr. 2018, 20, 397-417. [CrossRef]

38. Fusté-Forné, F.; Medina, F.X.; Mundet i Cerdan, L. La proximidad de los productos alimentarios: Turismo gastronómico y Mercados de abastos en la costa daurada (Cataluña, España). Rev. Geogr. Norte Gd. 2020, 76, 213-231. [CrossRef]

39. Mercer, L.K.; Song, H.R. Catalanidad in the Kitchen: Tourism, gastronomy and identity in modern and contemporary Barcelona. Bull. Span. Stud. 2020, 97, 659-680. [CrossRef]

40. Raina, A.; Singh, V.; Singh, A.; Kohli, V. Food culture as an element in promoting Punjab as a tourist destination. Test Eng. Manag. 2020, 82, 14187-14194.

41. Kim, S.; Iwashita, C. Cooking identity and food tourism: The case of Japanese udon noodles. Tour. Recreat. Res. 2016, 41, 89-100. [CrossRef]

42. Hall, C.M.; Sharples, L. The consumption of experiences or the experience of consumption? An introduction to the tourism of taste. In Food Tourism Around the World, Development, Management and Markets; Hall, C.M., Sharples, L., Mitchell, R., Macionis, N., Cambourne, B., Eds.; Butterworth Heinemann: Oxford, UK, 2003; pp. 13-36. 
43. Timothy, D.J.; Ron, A.S. Understanding heritage cuisines and tourism: Identity, image, authenticity, and change. J. Herit. Tour. 2013, 8, 99-104. [CrossRef]

44. UNWTO. Second Global Report on Gastronomy Tourism; UNWTO: Madrid, Spain, 2017.

45. Seyitoğlu, F.; Ivanov, S. A conceptual study of the strategic role of gastronomy in tourism destinations. Int. J. Gastron. Food Sci. 2020, 21, 100230. [CrossRef]

46. Quan, S.; Wang, N. Towards a structural model of the tourist experience: An illustration from food experiences in tourism. Tour. Manag. 2004, 25, 297-305. [CrossRef]

47. Morris, C.; Buller, H. The local food sector: A preliminary assessment of its form and impact in Gloucestershire. Br. Food J. 2003, 105, 559-566. [CrossRef]

48. Berno, T.; Laurin, U.; Maltezakis, G. The special role of agriculture in food tourism. In Have Fork Will Travel: Handbook for Food Tourism; Wolf, E., Lange-Faria, W., Eds.; World Food Travel Association: Portland, OR, USA, 2014; pp. $105-114$.

49. KPMG. La Gastronomía en la Economía Española; KPMG International: Madrid, Spain, 2019.

50. Pileri, P.; Moscarelli, R. From slow tourism to slow travel: An idea for marginal regions. In Cycling and Walking for Regional Development; Pileri, P., Moscarelli, R., Eds.; Springer: Cham, Switzerland, 2021; pp. 3-16.

51. Richards, G. From cultural tourism to creative tourism: European perspectives. Tourism 2002, 50, $225-233$.

52. Henderson, J.C. Food tourism reviewed. Br. Food J. 2009, 111, 317-326. [CrossRef]

53. Pérez Gálvez, J.C.; Granda, M.J.; López-Guzmán, T.; Coronel, J.R. Local gastronomy, culture and tourism sustainable cities: The behavior of the American tourist. Sustain. Cities Soc. 2017, 32, 604-612. [CrossRef]

54. PRODECA. Promotora dels Aliments Catalans. Available online: https://www.prodeca.cat/ca/sectors/el-sector-de-lacatalunya-agroalimentaria (accessed on 1 June 2021).

55. Carral, E.V.; Del Río, M.; López, Z. Gastronomy and Tourism: Socioeconomic and Territorial Implications in Santiago de Compostela-Galiza (NW Spain). Int. J. Environ. Res. Public Health 2020, 17, 6173. [CrossRef] [PubMed]

56. Cohen, E.; Avieli, N. Food in tourism: Attraction and impediment. Ann. Tour. Res. 2004, 31, 755-778. [CrossRef]

57. Eriksen, S.N. Defining local food: Constructing a new taxonomy-Three domains of proximity. Acta Agric. Scand. Sect. B Soil Plant Sci. 2013, 63 (Suppl. 1), 47-55. [CrossRef]

58. Henderson, J.C. Food and culture: In search of a Singapore cuisine. Br. Food J. 2014, 116, 904-917. [CrossRef]

59. Yankelevich, P. Alimentación e identidad nacional. Desacatos 2010, 34, 182-184. [CrossRef]

60. Reyes Uribe, A.C.; Guerra Avalos, E.A.; Quintero Villa, J.M. Educación en gastronomía: Su vínculo con la identidad cultural y el turismo. Periplo Sustentable 2017, 32.

61. Hashimoto, A.; Telfer, D.J. Selling Canadian culinary tourism: Branding the global and the regional product. Tour. Geogr. 2006, 8 , 31-55. [CrossRef]

62. Fernández-Poyatos, M.D.; Aguirregoitia Martínez, A.; Bringas Rábago, N.L. La cocina de producto: Seña de identidad y recurso de comunicación en la alta restauración en España. Rev. Lat. Comun. Soc. 2019, 74, 873-896.

63. Mohamed, M.E.; Hewedi, M.; Lehto, X.; Maayouf, M. Marketing local food and cuisine culture online: A case study of DMO's websites in Egypt. Int. J. Tour. Cities 2019, 6, 1045-1068. [CrossRef]

64. Hobsbawm, E.; Ranger, T. The Invention of Tradition; Cambridge University Press: Cambridge, UK, 1983.

65. Selwood, J. The lure of food: Food as an attraction in destination marketing in Manitoba. In Food Tourism Around the World, Development, Management and Markets; Hall, C.M., Sharples, L., Eds.; Butterworth Heinemann: Oxford, UK, 2003 ; pp. 178-180.

66. Scarpato, R.; Daniele, R. New global cuisine: Tourism, authenticity and sense of place in postmodern gastronomy. In Food Tourism Around the World, Development, Management and Markets; Hall, C.M., Sharples, L., Mitchell, R., Macionis, N., Cambourne, B., Eds.; Butterworth Heinemann: Oxford, UK, 2003; pp. 296-313.

67. Sims, R. Food, place and authenticity: Local food and the sustainable tourism experience. J. Sustain. Tour. 2009, 17, 321-336. [CrossRef]

68. Mak, A.H.; Lumbers, M.; Eves, A. Globalisation and food consumption in tourism. Ann. Tour. Res. 2012, 39, 171-196. [CrossRef]

69. Noguer-Juncà, E. La valoración de los paisajes rurales: El caso del valle de camprodón. In De Lugar Geográfico a Destino Turístico: Análisis, Planificación y Gestión de los Procesos de Cambio Generados por el Turismo; Somoza, J., Ed.; Universidad de León: León, Spain, 2018; pp. 451-461.

70. UNESCO. Mediterranean Diet. Available online: https:/ / ich.unesco.org (accessed on 1 June 2021).

71. Galí, N.; Donaire, J.A. The social construction of the image of Girona: A methodological approach. Tour. Manag. 2005, 26, 777-785. [CrossRef]

72. Galí, N.; Donaire, J.A. La imagen percibida por los turistas de la ciudad de Girona. Estud. Turísticos 2006, 168, 123-139.

73. Serra, S.F.; Blasco, D.; Palou, S. "Efecto Roca": El impacto del restaurante Celler de Can Roca en el turismo gastronómico de Cataluña. In Exam. De Tend. Del Tur. En El Umbral Del Siglo XXI; Martínez Moreno, O., Cuevas Contreras, T., Espinoza Sánchez, R., Eds.; Competitive Press: Benito Juárez, Mexico, 2016; pp. 119-130.

74. Björk, P.; Kauppinen-Räisänen, H. Local food: A source for destination attraction. Int. J. Contemp. Hosp. Manag. 2016, 28, 177-194. [CrossRef]

75. Fava, N.; Garrido Puig, R.; Carrasco Bonet, M.; Plana Ferrer, L. Els Mercats Municipals de la Provincia de Girona; Universitat de Girona: Girona, Spain, 2017. 
76. Alvado, A.; Sorribes, J.; Boyra, J. The tourist destination management and its dynamism: The case of barcelona versus Catalonia. Perspekt. Kult. 2021, 32, 171-188. [CrossRef]

77. Gössling, S.; Scott, D.; Hall, C.M. Pandemics, tourism and global change: A rapid assessment of COVID-19. J. Sustain. Tour. 2020, 29, 1-20. [CrossRef]

78. Associació de Comerciants de la Plaça del Mercat de Girona. Mercat del Lleó. Available online: https://www.mercatlleo.cat/ parades / fruita-verdura (accessed on 1 June 2021).

79. Okumus, B. Food tourism research: A perspective article. Tour. Rev. 2020, 76, 38-42. [CrossRef]

80. Bessière, J. Local development and heritage: Traditional food and cuisine as tourist attractions in rural areas. Sociol. Rural. 1998, 38, 21-34. [CrossRef]

81. Fusté-Forné, F. Cheese tourism in a world heritage site: Vall de Boí (Catalan Pyrenees). Eur. J. Tour. Res. 2015, 11, 87-101.

82. Hall, C.M.; Gössling, S. Food Tourism and Regional Development: Networks, Products and Trajectories; Routledge: London, UK, 2016.

83. Privitera, D.; Nedelcu, A.; Nicula, V. Gatronomic and food tourism as an economic local resource: Case studies from Romania and Italy. GeoJournal Tour. Geocities 2008, 21, 143-157.

84. Fox, R. Reinventing the gastronomic identity of Croatian tourist destinations. Int. J. Hosp. Manag. 2007, 26, 546-559. [CrossRef] 